\title{
Label-free Electrochemical Detection for Food Allergen using Screen Printed Carbon Electrode
}

\author{
Masato Saito, ${ }^{*}$ Masaaki Kitsunai, ${ }^{a}$ Minhaz Uddin Ahmed, ${ }^{\text {a,b }}$ Shigeru Sugiyama,c \\ and Eiichi TAMIYA ${ }^{\mathrm{a}}$
}

\begin{abstract}
aDepartment of Applied Physics, Graduate School of Engineering, Osaka University (2-1 Yamadaoka, Suita, Osaka 565-0871, Japan)

${ }^{b}$ School of Materials Science, Japan Advanced Institute of Science and Technology (1-1 Asahidai, Nomi, Ishikawa 923-1292, Japan)

'National Food Research Institute, National Agriculture and Food Research Organization (2-1-12 Kannondai, Tsukuba, Ibaraki 305-8642, Japan)
\end{abstract}

Received May 26, 2008 ; Accepted June 19, 2008

\begin{abstract}
Here we are reporting a new and rapid immunoassay for the food allergen using disposable screen printed carbon electrode (SPCE) in connection with the differential pulse voltammetry (DPV). Changes in the current signals due to antibody-antigen interaction provide the basis for an immunoassay on the SPCE surface which is simple, rapid, and cost effective. Casein, which is one of the most potent allergens in milk, was utilized as the model target in our experiment. After the immobilization of the anti-casein antibody on the pre-treated SPCE surface, sample solution contained casein was applied on the electrode surface and measured with DPV. Peak current due to casein was comparable while with bovine serum albumin (BSA) in solution. Our protocol is readily transferable for application to other immunological tests of food testing, because of this system is derived from utilizing the intrinsic electrochemical activity of antibody and antigen.
\end{abstract}

Key Words : Food Allergen, Label-free, Screen Printed Electrode

\section{Introduction}

Today, food allergy is recognized as a major health concern with an estimated $4 \%$ of the total population affected by food allergic disorders. ${ }^{1)}$ Cow milk allergies, is one of food allergies, represent an important health problem in industrialized countries. It can cause breathing problems, hives and rashes, abdominal pain, and possibly serious weight loss, especially in children. ${ }^{2)}$ Having a heat stable property, casein occupied $80 \%$ and has become the most prevalent allergen in more than 30 types of potentially allergy-causing proteins in milk. The lowest observed adverse effect levels (LOAELs) have been relatively consistent in reports about the milk allergens. Less than $350 \mathrm{mg}$ of protein in $1 \mathrm{~mL}$ of whole milk was determined as LOAELs for children, ${ }^{3)}$ and $0.5 \mathrm{~g}$ in freeze-dried milk (185 mg of protein) for adults. ${ }^{4}$ Milk is not only consumed as fresh milk but also supplied as many kinds of dairy products. Therefore, the development of casein testing kits is an important requirement in allergenic diagnosis.

Several immunological and DNA-based methods for the detection of food allergy have been reported such as gel electrophoresis, ${ }^{5,6)}$ RAST (radio-allergosorbent test), $\left.{ }^{7,8}\right)$ SPR, ${ }^{9,10)}$ ELISA (enzyme-linked immunosorbent assay),,11,12) and PCR (polymerase chain reaction). ${ }^{13-16)}$ Most of these methods required time-consuming sample purification, separation, and incubation steps. ELISA method, which can detect upto $1 \mathrm{ng} / \mathrm{mL}$ of the casein in milk sample has been widely used by researchers. However, the dis- advantages of the ELISA include its relatively time-consuming procedure $(\sim 4 \mathrm{~h})$ that requires skilled laborato-

(a)

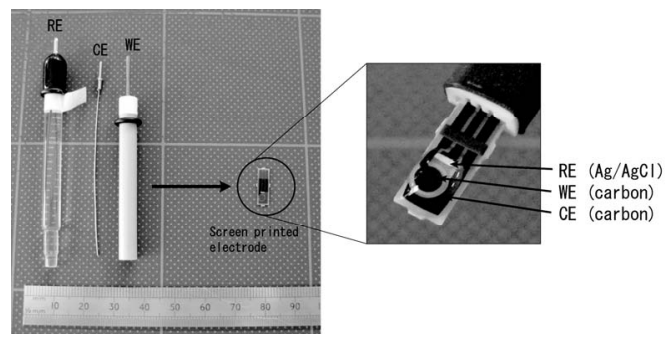

(b)

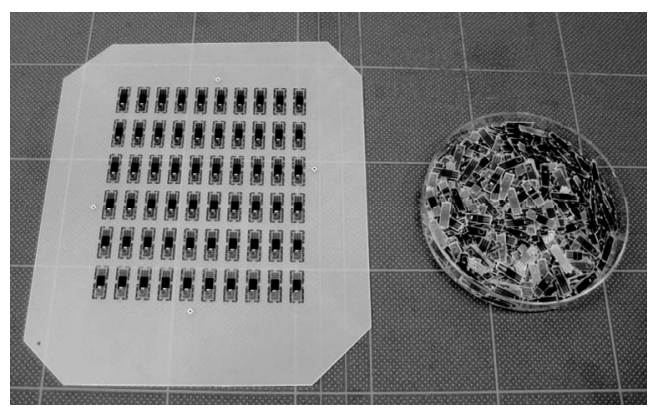

Fig. 1 Screen printed carbon electrode. (a) Three electrodes were miniaturized and integrated on one chip. (b) Chip electrodes were mass-produced as there were cost effective (left), and disposed off (right) after single use. 
ry technicians, as well as specialized laboratory equipments. Furthermore, DNA-based methods are not well suited for the detection of low DNA content e.g. available on eggs and milk.

Recently, label-free electrochemical detection of proteins has become an important topic in bioanalysis. ${ }^{17-20)}$ Our group has recently reported the electrochemical detection of amyloid peptides related to Alzheimer's disease by using intrinsic electro-activity. ${ }^{21)} \mathrm{We}$ also performed the label-free electrochemical immunoassay for human chorionic gonadotropin hormone (hCG) and human telomerase reverse transcriptase in urine sample. ${ }^{22,23)}$ Moreover, we have developed three-electrode type SPCE with the strong advantage of fabrication a large number of near identical electrodes at low cost (Fig. 1). ${ }^{24,25)}$ A sensitive SPCE immunosensor for the detection of hCG has also been developed by our group using the direct electrical detection of $\mathrm{Au}$ nanoparticles. ${ }^{26)}$ In this report, we have tried to develop an anti-allergen antibody-modified SPCE, and then detected the food allergen casein on the same electrode surface by using label-free voltammetry.

\section{1 Materials}

\section{Experimental}

Bovine-derived casein, bovine serum albmin (BSA), protein A, L-Tyrosin (L-Tyr) and L-Tryptophan (L-Trp) were obtained from Sigma (MO, USA). Anti-casein antibody from mouse was purchased from Cosmo Bio Co., Ltd. (Tokyo, Japan). 1-Ethyl-3-(3-dimethylaminopropyl) carbodiimide (EDC) was purchased from Dojindo (Kumamoto, Japan). N-Hydroxysulfosuccinimide (NHS) and all other chemical reagents were supplied by Wako Pure Chemicals Co (Tokyo, Japan) and were used as received. Ultrapure water, obtained from the NANOPureDIamond (Hansen \& Co., Ltd., Osaka, Japan), was used for the preparation of all solutions and for cleaning the electrodes.

\section{2 Procedure}

SPCE was electrochemically activated by applying various voltages of 0.5 to $1.5 \mathrm{~V}$ for 0 to $120 \mathrm{sec}$, which caused the formation of carboxylic groups on the carbon surface (Scheme 1a). Then, the working electrode (WE) surface of SPCE was covered with $5 \mu \mathrm{L}$ of $50 \mathrm{mM}$ phosphate buffer solution (PBS, pH 7.0) containing $5 \mathrm{mM}$ EDC and $8 \mathrm{mM}$ NHS for $1 \mathrm{~h}$ to activate carboxyl group. After rinsing with ultrapure water, $5 \mu \mathrm{L}$ of $100 \mu \mathrm{g} / \mathrm{mL}$ protein A in acetate buffer ( $3 \mathrm{mM}$ acetic acid and $7 \mathrm{mM}$ sodium acetate, $\mathrm{pH}$ 4.8) was put onto the WE surface and left to react for $1 \mathrm{~h}$ at room temperature to couple the lysine residues of protein A to the covalently activated electrodes. Protein A-modified electrode was then extensively rinsed with water. Then, the protein A-modified WE surface was covered with $5 \mu \mathrm{L}$ of $20 \mu \mathrm{g} / \mathrm{mL}$ anti-casein antibody in PBS and allowed to interact with the Fc fragment of the antibodies for $1 \mathrm{~h}$ to yield the sensing interface. The unbound antibody was washed away while treated with PBS. Anti-casein antibody-modified WE of SPCE then treated with $5 \mu \mathrm{L}$ of casein solution in its various concentration for $1 \mu \mathrm{g} / \mathrm{mL}$ to $100 \mu \mathrm{g} / \mathrm{mL}$ and incubated for $1 \mathrm{~h}$. Schematic illustration of the modification process was shown in scheme 1.

\section{3 Apparatus}

SPCE consisted of a carbon working electrode, a carbon counter electrode, and $\mathrm{Ag} / \mathrm{AgCl}$ reference electrode. SPCEs were provided by Bio Device Technology Co. Ltd. (Ishikawa, Japan). Total length of a SPCE was $11 \mathrm{~mm}$, and the geometric working area was $2.64 \mathrm{~mm}^{2}$ (Fig. 1). Electrochemical measurements were performed in $20 \mu \mathrm{L}$ of PBS covering all three electrodes. All measurements were carried out at room temperature. Differential pulse voltammetry (DPV) was performed with an Autolab PGSTAT 12 electrochemical analysis system (Eco Chemie, The Netherlands) in connection with its general purpose electrochemical system software. The raw voltammograms were treated using Savitzky-Golay smoothing (level 4). For electrochemical measurement, each SPCE was used once, and discarded after each measurement. Since the electrochemical protein oxidation signal is irreversible and only one measurement can be performed only once, disposable SPCE should be suitable candidates for future applications in our method.

\section{Results and Discussion}

Aromatic amino acids, tryptophan(Trp) and tyrosine(Tyr) expressed redox activity and were used as indicator for electrochemical immunoassay. ${ }^{23)}$ At first we verified the electrochemical activity of Trp, Tyr, casein and BSA with DPV measurements on the bare SPCE in PBS. The voltammetric peaks with $100 \mu \mathrm{g} / \mathrm{mL}$ Tyr and Trp were appeared around $0.38 \mathrm{~V}$ (vs. $\mathrm{Ag} / \mathrm{Ag} / \mathrm{Cl}$ ) and $0.47 \mathrm{~V}$ on bare SPCEs, respectively (Fig. 2A). BSA and

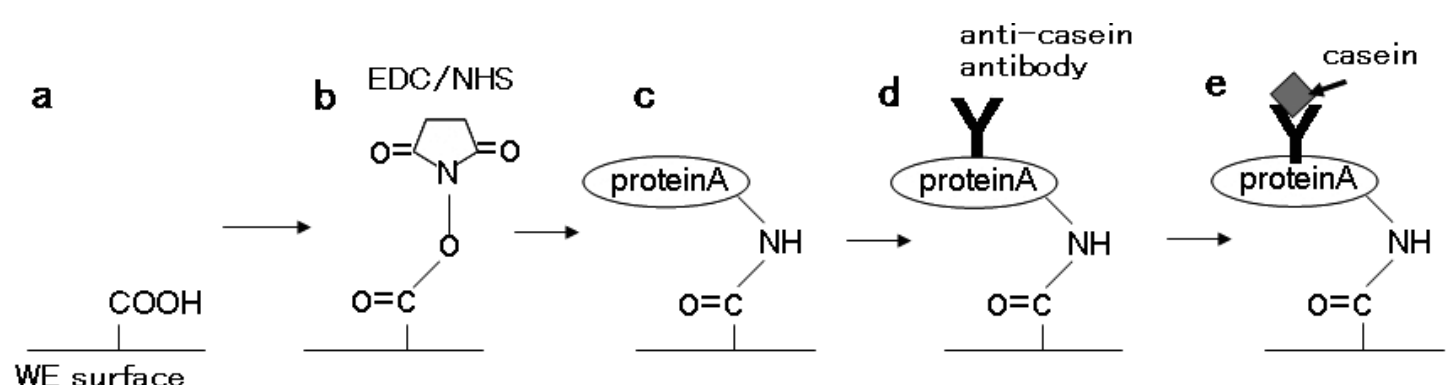

Scheme 1 Schematic illustration of the modification process of anti-casein antibody and casein on WE surface. (a) WE surface was oxidized to form the carboxyl group. (b) Carboxyl group was activated by EDC and NHS. (c) Protein A was immobilized chemically. (d) Anti-casein antibody binds with Protein A. (e) Casein was captured by anti-casein antibody. 
casein indicated similar oxidation peak potentials with Tyr and Trp (Fig. 2B). Casein consisted of four subunits which were called as $\alpha$-s1, $\alpha$-s2, $\beta$ and $\kappa$, totally including thirty five Tyr and six Trp residues (accession numbers in PubMed: $\alpha$-s1-casein, NP_851372; $\alpha$-s2-casein, NP_776953; $\beta$-casein, NP_851351; $\kappa$-casein, NP_776719). Quantity and spatial location of these amino acid residues may be the key factors for electron transfer to the electrode.

Oxidation treatment induced to form the carboxyl groups onto WE surface. To optimize the immobilization of anti-casein antibody and protein A, DPV measurements onto the WE surface were carried out. Initially, to form the carboxyl groups on WE surface, WE was treated by applying voltage from $0.5 \mathrm{~V}$ to $1.5 \mathrm{~V}$ for several times, then the protein A was immobilized onto WE surface by the conventional method described in the experimental section. The oxidation peak current of protein $\mathrm{A}$ was observed at $0.40 \mathrm{~V}$ (vs. $\mathrm{Ag} / \mathrm{Ag} / \mathrm{Cl}$ ). Figure 3 indicated the effect of peak current intensities of the WE modified with protein $\mathrm{A}$ on reaction time under different volt-

(A)

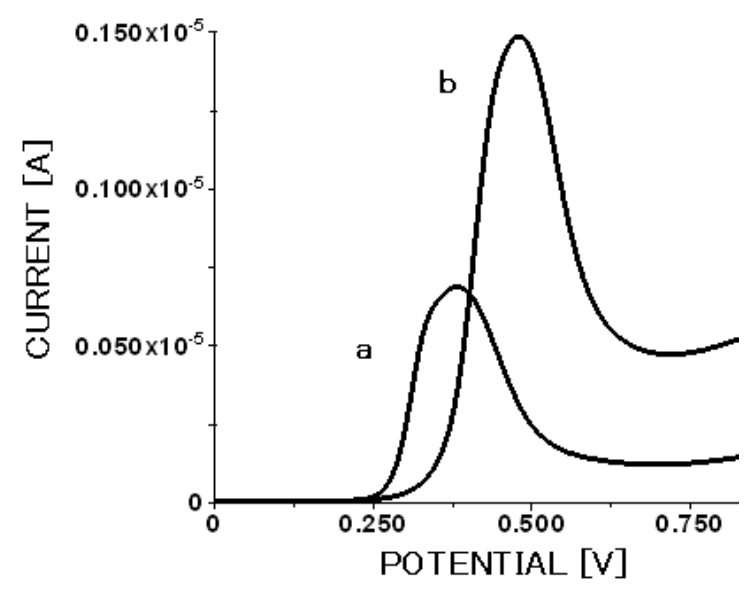

(B)

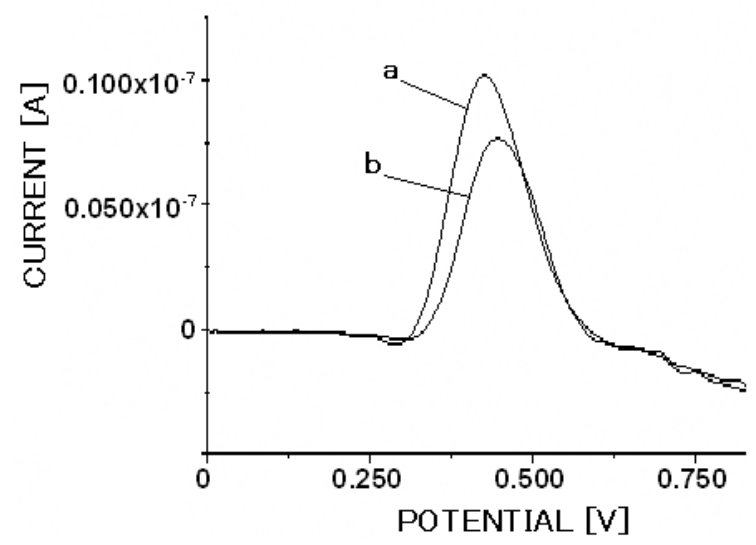

Fig. 2 Differential pulse voltammetry for the electrochemical active amino acids and food allergen proteins in $50 \mathrm{mM}$ PBS (pH 7.0) at SPCE: (A) a: $100 \mu \mathrm{g} / \mathrm{mL}$ Tyr, b: $100 \mu \mathrm{g} / \mathrm{mL}$ Trp. (B) a: $10 \mu \mathrm{g} / \mathrm{mL}$ casein, b: $10 \mu \mathrm{g} / \mathrm{mL}$ BSA. ages. We obtained the increased peak current due to protein oxidation in case of $1.0 \mathrm{~V}$ in $60 \mathrm{sec}$. This indicates that the carboxyl group was generated sufficiently and Protein A could be immobilized onto the WE surface at this pretreatment condition. On the other hand, the decreased peak current was observed at $0.5 \mathrm{~V}$ and $1.5 \mathrm{~V}$. Analyzing these results, we have determined that $1.0 \mathrm{~V}$ and $60 \mathrm{sec}$ were determined for applying voltage and operation time, respectively.

Pre-treated protein A-modified WE was then mixed with $5 \mu \mathrm{L}$ of anti-casein antibody. After incubation for 1 $\mathrm{h}$ at room temperature, SPCE was washed with ultra pure water. Then, $5 \mu \mathrm{L}$ of casein solution was dropped onto the anti-casein-modified WE and was incubated for $1 \mathrm{~h}$. Casein was then captured on the WE surface by antigen-antibody reaction. After washing by PBS to remove the unbound casein, DPV measurement was performed while the SPCE surface was layered with PBS. We obtained significant difference of current peak value using BSA as negative control. Figure 4 showed the DPV data obtained from the direct oxidation of equal quantity $(10 \mu \mathrm{g} / \mathrm{mL})$ of casein in PBS (Fig. $4 \mathrm{~A}-\mathrm{a})$ and BSA (Fig. 4A-b). The current signal of the anti-casein antibody-protein A modified electrode was shown in Fig. 4A-c. Modification process only with protein $\mathrm{A}$ and antibody were also indicated by Figs. 4A-c and 4A-d. Further research about the intrinsic electrochemical activity of antibodies and their targets would surely provide simplified screening assays, as well as extensive data regarding their interaction mechanisms. Figure 4B showed the dependency of current peak signal on various casein concentrations $(1 \mu \mathrm{g} / \mathrm{mL}, 10 \mu \mathrm{g} / \mathrm{mL}$ and 100 $\mu \mathrm{g} / \mathrm{mL}$ ). As a result, the higher amounts of casein caused to the bigger change in the current peak values (each concentration was repeated three times).

Our method provided allergen measurement chemical-

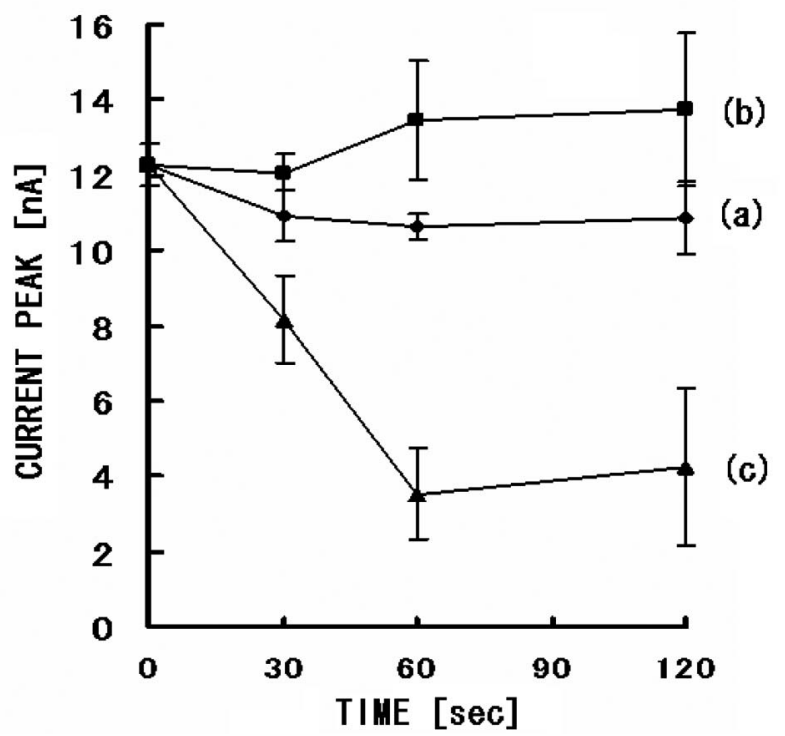

Fig. 3 DPV measurement of protein A modified SPCE, which were treated by applying voltages of $0.5 \mathrm{~V}$ (a), $1.0 \mathrm{~V}$ (b) and $1.5 \mathrm{~V}$ (c) on different time from 0-120 sec. Error bars indicate the standard deviation of at least three replicated measurement $(\mathrm{n}=3)$. 
(A)

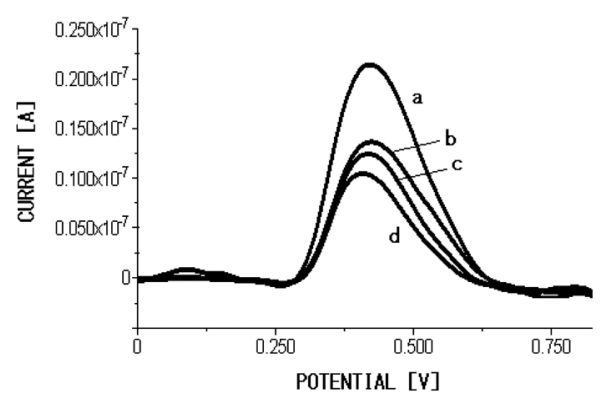

(B)

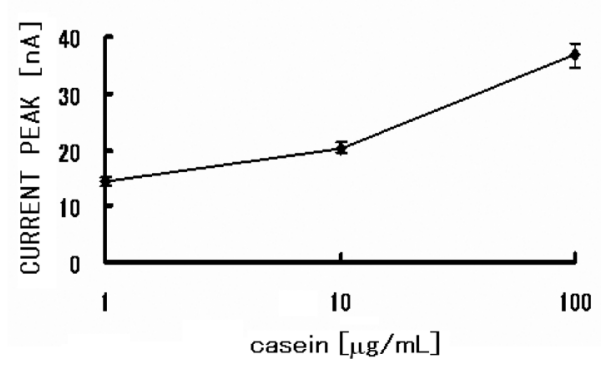

Fig. 4 Label-free electrochemical measurement based on casein and anti-casein antibody reaction. (A) DPV measurement for casein: (a) $10 \mu \mathrm{g} / \mathrm{mL}$ casein in PBS at casein antibody/protein A-modified SPCE; (b) $10 \mu \mathrm{g} / \mathrm{mL}$ BSA in PBS at casein antibody/protein A-modified SPCE; (c) PBS at casein antibody/protein A-modified SPCE; (d) PBS at protein A-modified SPCE. (B) Plot for the dependence of electrochemical signal obtained from different concentration of casein in $50 \mathrm{mM}$ PBS ( $\mathrm{pH}$ 7.0).

ly by casting sample on the pretreated SPCE, and this technique is readily applicable without any technical skill. Moreover, since the principle of this determination relies on the intrinsic electrochemical activity of the antibody proteins, which includes Tyr and Trp oxidation at carbon electrode, so, this method can help to detect other food allergen/proteins. Although, the current detection limit is not good as ELISA method, but it is still enough for many practical applications. We trust deeply that a lower detection limit can be attained by optimization the detection chemistry such as surface density, competitive immunoassay etc.

\section{Conclusion}

A simplified food allergen immunosensor was developed using the electrochemical detection of protein oxidation in connection with the disposable SPCE. We have used casein, derived from bovine, as a model target for our detection platform. The required antigen sample volume was only $5 \mu \mathrm{L}$, and a series of procedures could be performed only on one surface. Our protocol is readily transferable for application to other immunological tests of food testing, because of this system is derived from utilizing the intrinsic electroactivity of antibody and antigen.

\section{References}

1) A. J. van Hengel, Anal. Bioanal. Chem., 389, 111 (2007).

2) H. A. Sampson, J. Allergy Clin. Immunol., 113, 805 (2004).

3) B. Bellioni-Businco, R. Paganelli, P. Lucenti, P. G. Giampietro, H. Perborn, and L. Businco, J. Allergy Clin. Immunol., 103, 1191 (1999).

4) E. A. Pastorello, L. Stocchi, V. Pravettoni, A. Bigi, M. L. Schilke, C. Incorvaia, and C. Zanussi, J. Allergy Clin. Immunol., 84, 475 (1989).

5) I. Malmheden Yman, A. Eriksson, G. Everitt, L. Yman, and T. Karlsson, Food Agric. Immunol., 6, 167 (1994).

6) T. Holzhauser, L. I. Dehne, A. Hofmann, D. Haustein, and S. Vieths, Zeitschrift fuer Lebensmittel-Untersuchung und-Forschung, 206, 1 (1998).

7) S. Fremont, G. Kanny, S. Bieber, J. P. Nicolas, and D. A. Moneret-Vautrin, Allergy, 51, 749 (1996).

8) S. J. Koppelman, A. C. Knulst, W. J. Koers, A. H. Penninks, H. Peppelman, R. Vlooswijk, I. Pigmans, G. van Duijn, and M. Hessing, J. Immunol. Methods, 229, 107 (1999).

9) S. Muller-Renaud, D. Dupont, and P. Dulieu, J. Agric. Food Chem., 52, 659 (2004).

10) S. Muller-Renaud, D. Dupont, and P. Dulieu, J. Dairy Res., 72, 57 (2005).

11) S. J. Koppelman, H. Bleeker-Marcelis, G. Duijn, and M. Hessing, World Ingred, 12, 35 (1996).

12) T. Holzhauser and S. Vieths, J. Agric Food Chem., 47, 603 (1999).

13) T. Hirao, S. Imai, H. Sawada, N. Shiomi, S. Hachimura, and H. Kato, Biosci. Biotechnol. Biochem., 69, 724 (2005).

14) T. Holzhauser, O. Stephan, and S. Vieths, J. Agric. Food Chem., 50, 5808 (2002).

15) H. Hird, J. Lloyd, R. Goodier, J. Brown, and P. Reece, Eur. Food Res. Technol., 217, 265 (2003).

16) O. Stephan and S. Vieths, J. Agric. Food Chem., 52, 3754 (2004).

17) M. Masarik, R. Kizek, K. J. Kramer, S. Billova, M. Brazdova, J. Vacek, M. Bailey, F. Jelen, and J. A. Howard, Anal. Chem., 75, 2663 (2003).

18) M. Masarik, A. Stobiecka, R. Kizek, F. Jelen, Z. Pechan, W. Hoyer, T. M. Jovin, V. Subramaniam, and E. Palecek, Electroanalysis, 16, 1172 (2004).

19) E. Palecek, M. Masarik, R. Kizek, D. Kuhlmeier, J. Hassmann, and J. Schulein, Anal. Chem., 76, 5930 (2004).

20) E. Palecek, F. Scheller, and J. Wang, Eds. Electrochemistry of nucleic acids and proteins, Elsevier, Amsterdam (2005).

21) M. Vestergaard, K. Kerman, M. Saito, M. Nagatani, Y. Takamura, and E. Tamiya, J. Am. Chem. Soc., 127, 11892 (2005).

22) M. Takata, K. Kerman, N. Nagatani, H. Konaka, M. Namiki, and E. Tamiya, J. Electroanalytical Chem., 586, 109 (2006)

23) K. Kerman, N. Nagatani, M. Chikae, T. Yuhi, Y. Takamura, and E. Tamiya, Anal. Chem., 78, 5612 (2006)

24) M. Chikae, K. Idegami, K. Kerman, N. Nagatani, M. Ishikawa, Y. Takamura, and E. Tamiya, Electrochem. Communi., 8, 1375 (2006)

25) M. U. Ahmed, K. Idegami, M. Chikae, K. Kerman, P. Chaumpluk, S. Yamamura, and E. Tamiya, Analyst, 132, 431 (2007).

26) K. Idegami, M. Chikae, K. Kerman, N. Nagatani, T. Yuhi, T. Endo, and E. Tamiya, Electroanalysis, 20, 14 (2008). 